\title{
Comparison of the Chemical Composition of the Essential Oils from the Fresh and Dried Leaves of Greenwayodendron suaveolens (Engl. \& Diels)
}

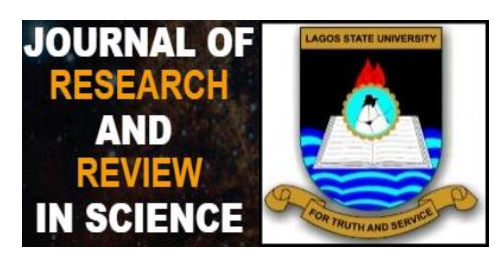

\section{Oseyemi O. Olubomehin $1^{1}$, Odunayo C. Atewolara-Odule $2^{1}$, Abdulrazaq O. Ogunmoye $3^{1}$}

${ }^{1}$ Department of Chemical Sciences, Faculty of Science, Olabisi Onabanjo University, P.M.B. 2002, Ago-Iwoye, Ogun State, Nigeria

\section{Correspondence}

Oseyemi Omowunmi Olubomehin, Department of Chemical Sciences, Faculty of Science, Olabisi Onabanjo University, P.M.B. 2002, AgoIwoye, Ogun State, Nigeria.

Email:olubomehin.oseyemi@oouagoiwoye.edu.ng

\section{Funding information}

Not applicable

\begin{abstract}
:
Introduction: Greenwayodendron suaveolens (Engl. \& Diels) is a tree with a straight regular trunk, dark bark as well as a small crown with horizontal branches. Its bark and roots are used for vermifuges, and aphrodisiac while the leaf is used as a pain-killer, and a cure for dysenteries and fevers.

Aims: This work sets out to identify and compare the essential oil constituents of the fresh and dried leaves of Greenwayodendron suaveolens.

Materials and Methods: Greenwayodenron Suaveolens leaves were collected at the biology farm of Olabisi Onabanjo University Ago-Iwoye, Ogun State and extracted by hydro-distillation using Clevenger apparatus. The qualitative and quantitative analyses of the wet and dried leaf essential oils were performed using Gas Chromatography (GC) and Gas Chromatography-Mass Spectrometry (GC-MS).

Results: From the GC-MS analysis, twenty-eight (28) compounds were identified in the fresh sample, while the dried sample had fourteen (14). The major components were: Caryophyllene, $20.85 \%$ and $22.13 \%$; $\alpha$ Zingiberene, $16.55 \%$ and $17.00 \%$; Aromandendrene, $9.24 \%$ and $11.14 \%$; Humulene, $9.08 \%$ and $9.92 \%$; Caryophyllene oxide, $5.68 \%$ and $4.29 \%$ for the fresh and dried samples respectively. Curcumene, 20.89\% occurred only in the dried sample.

Conclusion: This study presents the results of the essential oil composition of the fresh and dried leaf samples of Greenwayodendron suaveolens which will be useful in research. The presence of sesquiterpenes as the major components of both oils justifies the traditional use of the plant in treating pains, headaches and inflammations.

To Keywords: Greenwayodendron suaveolens, Clevenger apparatus, hydrodistillation, essential oil.
\end{abstract}




\section{INTRODUCTION}

Greenwayodendron suaveolens (Engl. \& Diels) Verdc, belongs to the Annonaceae family. It is widespread in West and Central Africa in such countries as Côte d'Ivoire, Gabon, Angola, Cameroon, Nigeria, Tanzania, Democratic Republic of Congo and Uganda [1]. Greenwayodendron suaveolens is a tree of the highforest reaching to about a height of $20 \mathrm{~m}$ in Southern Nigeria [2] with some of its common vernacular names in Nigeria including 'éwáé' in Edo, 'Eleku' in Isekiri, and 'Agudugbu/Awuje' in Yoruba [3]. The dark bark and straight regular trunk of this tree, as well as the small crown with horizontal branches, make it easy to recognize. The wood is pale brown, fine-grained, of good quality used for furniture and construction work. It is often valued for firewood and is very important in pharmaceutics research because of the antifungal, bacteriostatic, and especially cytostatic capabilities of some chemical constituents of the leaves and bark [4, 5]. The fruit which has a very long fruiting season is green when immature, turns almost black when, ripe is widely consumed by many animals [6]. The roots, leaves and barks of this plant are used in traditional medicine for the treatment of fever, rheumatism pains, oedema, swollen glands, headache, stomach ache, constipation, hernia, facilitation of childbirth, fertility, anthelmintic, aphrodisiac and as ornamentals [7, 8]. In Cameroon and Gabon, the bark is applied to scarification for the treatment of malaria. In Democratic Republic of Congo, pounded bark is used in a mixture with other plants to make arrow poison while in Nigeria, the leaf has been recorded to be taken internally for menorrhagia; the fruit is equally edible [9]. Suaveolindole obtained from Greenwayodendron suaveolens was found to possess significant in vitro antibacterial activity against the Gram-positive bacteria; Bacillus subtilis, Staphylococcus aureus and methicillin-resistant Staphylococcus aureus, [10]. However, there has been no report of the essential components of the leaf and hence this research works sets out to do this.

\section{MATERIALS AND METHODS}

\subsection{Plant materials}

Fresh leaves (1 kg) of Greenwayodendron suaveolens were collected at Olabisi Onabanjo University, AgoIwoye. The plant was identified in the University's Department of Plant Science and Applied Zoology and authenticated at the herbarium of the Forestry Research Institute of Nigeria (FRIN), Ibadan by Mr. A. $\mathrm{S}$. Odewo where a voucher specimen with $\mathrm{FHI}$ number 111865 was deposited.

\subsection{Isolation of Essential Oils}

The fresh $(500 \mathrm{~g})$ and dried $(250 \mathrm{~g})$ leaves were hydrodistilled in an all glass Clevenger-type apparatus for four hours $(4 \mathrm{~h})$ in each case. The oils obtained were dried over anhydrous sodium sulphate $\left(\mathrm{Na}_{2} \mathrm{SO}_{4}\right)$, stored in vials and kept inside a refrigerator until ready for analysis.

\subsection{Gas chromatography (GC)}

The essential oils were subjected to $G C$ analyses on an Agilent technology 7890 model with splitless mode and HP-5973 at $70 \mathrm{eV}$ with mass range $\mathrm{m} / \mathrm{z}$ 40-420. The column was HP-5MS ( $30 \times 0.32 \mathrm{~mm}, 0.25 \mu \mathrm{m}$ film thickness) and the inlet pressure was $100.2 \mathrm{kPa}$. Helium was used as carrier gas at a flow rate of 1 $\mathrm{mL} / \mathrm{min}$. The GC oven temperature was programmed at $60^{\circ} \mathrm{C}$ (held for $0 \mathrm{~min}$ ), heated to $140^{\circ} \mathrm{C}$ at $3^{\circ} \mathrm{C} / \mathrm{min}$ with a final hold time of $10 \mathrm{~min}$ at $280^{\circ} \mathrm{C}$. Injector and detector temperatures were fixed at $200^{\circ} \mathrm{C}$ and $250^{\circ} \mathrm{C}$ respectively.

\subsection{Gas chromatography-mass spectrometry (GC-MS)}

The GC-MS analyses were performed on an Agilent technology 7890 with splitless injector interfaced to a 5973 and 7683 mass selective detector operated at 70 $\mathrm{eV}$ with a mass range of $\mathrm{m} / \mathrm{z}$ 40-450. The oven temperature was programmed from $60-280^{\circ} \mathrm{C}$ (hold for 5 minutes) at a rate of $3^{\circ} \mathrm{C} / \mathrm{min}$. The same operations and temperature programmings were used as for GC. FID chromatogram was used to calculate the relative percentage amounts of the separated compounds.

\subsection{Identification of components}

Identification of the essential oil components was based on their retention indices (determined with reference to a homologous series of n-alkanes) and by comparison of their mass spectral fragmentation patterns in computer matching against in-built data (NIST database/ Chemstation data system) with data previously reported in the literature [11] and the use of pherobase.

\section{RESULTS}

From Table I, a total of twenty-eight (28) compounds were detected representing $98.02 \%$ of the essential oil corresponding to $67.73 \%$ sesquiterpenes, $13.79 \%$ oxygenated sesquiterpenes, $6.21 \%$ terpenes, $3.02 \%$ heterocyclic compounds, $5.79 \%$ hydrocarbons and $1.48 \%$ esters. From Table II, a total of fourteen (14) compounds were detected representing $100 \%$ essential oil composition comprising $88.90 \%$ Sesquiterpenes, $8.32 \%$ Oxygenated sesquiterpenes, $1.80 \%$ Terpenes and $0.98 \%$ Hydrocarbons. 
Table I: Chemical composition of essential oils of the fresh leaves of Greenwayodendron suaveolens

\begin{tabular}{|c|c|c|c|c|c|c|}
\hline $\begin{array}{l}\text { Compd } \\
\text { No. }\end{array}$ & $\begin{array}{l}\text { RT } \\
\text { Min }\end{array}$ & $\mathbf{R I}$ & Identified Compounds & $\begin{array}{l}\% \\
\text { Composition }\end{array}$ & $\begin{array}{l}\text { Molecular } \\
\text { Formula }\end{array}$ & MS $^{a, b}$ \\
\hline 1. & 3.304 & 1040 & ß.-Ocimene & 3.48 & $\mathrm{C}_{10} \mathrm{H}_{16}$ & $\begin{array}{l}93^{\mathrm{a}}, 41,53,77,79 \\
91,105,121,136^{\mathrm{b}}\end{array}$ \\
\hline 2. & 6.257 & 1280 & (-)-Bornyl acetate & 0.66 & $\mathrm{C}_{12} \mathrm{H}_{20} \mathrm{O}_{2}$ & $\begin{array}{l}95^{\mathrm{a}}, 43,93,121,136 \\
, 154,196^{\mathrm{b}}\end{array}$ \\
\hline 3. & 7.264 & NA & $\begin{array}{l}\text { Acetic Acid, } 1,7,7- \\
\text { trimethyl-bicyclo } \\
\text { [2.2.1]hept-2-ylester }\end{array}$ & 0.82 & $\mathrm{C}_{12} \mathrm{H}_{20} \mathrm{O}_{2}$ & $\begin{array}{l}95^{\mathrm{a}} \cdot 43,93,108,121 \\
, 136,154,196^{\mathrm{b}}\end{array}$ \\
\hline 4. & 9.690 & 1451 & Caryophyllene & 20.85 & $\mathrm{C}_{15} \mathrm{H}_{24}$ & $\begin{array}{l}93^{\mathrm{a}}, 41,55,69,79 \\
91,106,120,147 \\
161,189,204^{\mathrm{b}}\end{array}$ \\
\hline 5. & 9.816 & 1428 & $\alpha$-Bergamotene & 1.38 & $\mathrm{C}_{15} \mathrm{H}_{24}$ & $\begin{array}{l}93^{\mathrm{a}}, 41,55,69,77 \\
91,107,161,204^{\mathrm{b}}\end{array}$ \\
\hline 6. & 10.211 & 1456 & Humulene & 9.08 & $\mathrm{C}_{15} \mathrm{H}_{24}$ & $\begin{array}{l}93^{\mathrm{a}}, 41,80,121,147 \\
, 204^{\mathrm{b}}\end{array}$ \\
\hline 7. & 10.354 & 1440 & Aromandendrene & 9.24 & $\mathrm{C}_{15} \mathrm{H}_{24}$ & $\begin{array}{l}41^{a}, 55,69,79,91 \\
105,119,133,147 \\
161,189,204^{b}\end{array}$ \\
\hline 8. & 10.508 & 1473 & Y,-Muurolene & 0.73 & $\mathrm{C}_{15} \mathrm{H}_{24}$ & $\begin{array}{l}161^{\mathrm{a}}, 41,55,69,79,93 \\
105,119,133, \\
189,204^{\mathrm{b}}\end{array}$ \\
\hline 9. & 10.633 & 1439 & (E)- $\beta$-Famesene & 3.82 & $\mathrm{C}_{15} \mathrm{H}_{24}$ & $\begin{array}{l}41^{\mathrm{a}}, 69,93,120,133 \\
, 161,204^{\mathrm{b}}\end{array}$ \\
\hline 10. & 10.726 & 1464 & $\begin{array}{l}\text { Naphthalene, decahydro- } \\
\text { 4a-methyl-1-methylene-7- } \\
\text { (1-methylethenyl)-, [4aR- } \\
(4 a \alpha, 7 a, 8 a \beta)]-\end{array}$ & 2.06 & $\mathrm{C}_{15} \mathrm{H}_{24}$ & 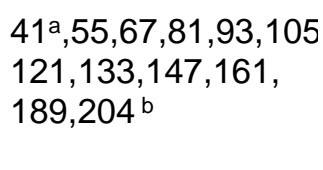 \\
\hline 11. & 10.914 & 1493 & a-Zingiberene & 16.55 & $\mathrm{C}_{15} \mathrm{H}_{24}$ & $\begin{array}{l}93^{\mathrm{a}}, 41,69,119,161 \\
, 204^{\mathrm{b}}\end{array}$ \\
\hline 12. & 11.029 & 1519 & $\beta$-Bisabolene & 0.40 & $\mathrm{C}_{15} \mathrm{H}_{24}$ & $\begin{array}{l}69^{a}, 41,93,109,161 \\
204^{b}\end{array}$ \\
\hline 13. & 11.281 & 1530 & $\beta$-Sesquiphellandrene & 1.50 & $\mathrm{C}_{15} \mathrm{H}_{24}$ & $\begin{array}{l}69^{\mathrm{a}}, 41,55,71,93 \\
109,120,133,161 \\
204^{\mathrm{b}}\end{array}$ \\
\hline 14. & 11.750 & NA & Patchoulane & 0.58 & $\mathrm{C}_{15} \mathrm{H}_{26}$ & $\begin{array}{l}41^{\mathrm{a}, 29,55,67,79} \\
91,107,121,206^{\mathrm{b}}\end{array}$ \\
\hline 15. & 12.099 & NA & Cytosine & 1.46 & $\mathrm{C}_{4} \mathrm{H}_{5} \mathrm{~N}_{3} \mathrm{O}$ & $41^{\mathrm{a}}, 69,83,111^{\mathrm{b}}$ \\
\hline 16. & 12.288 & 1579 & $\begin{array}{l}\text { Caryophyllene } \\
\text { Oxide }\end{array}$ & 5.68 & $\mathrm{C}_{15} \mathrm{H}_{24} \mathrm{O}$ & $\begin{array}{l}43^{\mathrm{a}}, 41,55,69,79,93 \\
109,121,220^{\mathrm{b}}\end{array}$ \\
\hline 17. & 12.591 & NA & 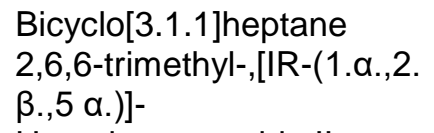 & 2.61 & $\mathrm{C}_{10} \mathrm{H}_{18}$ & $\begin{array}{l}55^{\mathrm{a}}, 41,67,69,82,96 \\
, 123,138^{\mathrm{b}}\end{array}$ \\
\hline 18. & 12.677 & 1605 & Humulene epoxide II & 1.36 & $\mathrm{C}_{15} \mathrm{H}_{24} \mathrm{O}$ & $\begin{array}{l}109^{\mathrm{a}}, 43,55,67,96 \\
123,138,220^{\mathrm{b}}\end{array}$ \\
\hline 19. & 12.768 & 1611 & Zingiberenol & 4.81 & $\mathrm{C}_{15} \mathrm{H}_{26} \mathrm{O}$ & $\begin{array}{l}69^{\mathrm{a}}, 41,93,119,161 \\
, 204,222^{\mathrm{b}}\end{array}$ \\
\hline 20. & 13.083 & NA & Oxirane, 3-butenyl & 1.56 & $\mathrm{C}_{6} \mathrm{H}_{10} \mathrm{O}$ & $\begin{array}{l}67^{\mathrm{a}}, 31,41,54,68,79 \\
, 83,98^{\mathrm{b}}\end{array}$ \\
\hline 21. & 13.152 & 998 & 2-Carene & 1.92 & $\mathrm{C}_{10} \mathrm{H}_{16}$ & $\begin{array}{l}93^{\mathrm{a}}, 79,91,105,121 \\
136^{\mathrm{b}}\end{array}$ \\
\hline 22. & 13.398 & NA & Neointermedeol & 1.46 & $\mathrm{C}_{15} \mathrm{H}_{26} \mathrm{O}$ & $\begin{array}{l}43^{\mathrm{a}}, 67,71,81,136 \\
161,189,204,222^{\mathrm{b}}\end{array}$ \\
\hline 23. & 13.455 & NA & $\begin{array}{l}\text { 9-(1-Methylethylidene)- } \\
\text { bicyclo[6.1.0]nonane }\end{array}$ & 1.69 & $\mathrm{C}_{12} \mathrm{H}_{20}$ & $\begin{array}{l}41^{\mathrm{a}}, 55,67,79,81 \\
93,107,121,136 \\
148,164^{\mathrm{b}}\end{array}$ \\
\hline 24. & 13.558 & NA & $\begin{array}{l}\text { (E)-2,5-Dimethyl-1,6- } \\
\text { octadiene }\end{array}$ & 0.50 & $\mathrm{C}_{10} \mathrm{H}_{18}$ & $\begin{array}{l}41^{a}, 55,69,82,109, \\
138^{b}\end{array}$ \\
\hline 25. & 13.655 & 1036 & Z-Ocimene & 0.81 & $\mathrm{C}_{10} \mathrm{H}_{16}$ & $93^{a}, 41,53,79,105$, \\
\hline
\end{tabular}




\begin{tabular}{|c|c|c|c|c|c|}
\hline 13.764 & 1680 & a-Bisabolol & 0.48 & $\mathrm{C}_{15} \mathrm{H}_{26} \mathrm{O}$ & $\begin{array}{l}121,136^{b} \\
43^{a}, 69,95,109,119 \\
, 161,204^{b}\end{array}$ \\
\hline 13.850 & NA & y-Curcumene & 1.55 & $\mathrm{C}_{15} \mathrm{H}_{24}$ & $\begin{array}{l}119,93,105,134 \\
161,204 \text { b }\end{array}$ \\
\hline 18.033 & NA & $\begin{array}{l}\text { Cyclohexane,1,5- } \\
\text { diethenyl-2,3-dimethyl- } \\
\text {,(1.alpha.,2.beta.,3.beta.,5 } \\
\text {.beta.)- }\end{array}$ & 0.99 & $\mathrm{C}_{12} \mathrm{H}_{20}$ & $\begin{array}{l}107^{\mathrm{a}}, 41,55,67,79 \\
93,121,136,149 \\
160^{\mathrm{b}}\end{array}$ \\
\hline
\end{tabular}

Key:RT- Retention time in minutes, RI-Kovat values from literature, NA-Kovat values from literature not available,

$\mathrm{MS}{ }^{\mathrm{ab}} \mathrm{a}=$ base peak, $\mathrm{b}=$ Molecular ion peak.

Table II: chemical composition of essential oils of the dried leaves of Greenwayodendron suaveolens

\begin{tabular}{|c|c|c|c|c|c|c|}
\hline $\begin{array}{r}\text { Compd } \\
\text { No. }\end{array}$ & RT Min & $\mathbf{R I}$ & $\begin{array}{l}\text { Identified } \\
\text { Compounds }\end{array}$ & $\begin{array}{l}\text { \% } \\
\text { Composition }\end{array}$ & $\begin{array}{l}\text { Molecular } \\
\text { Formula }\end{array}$ & $\mathrm{MS}^{\mathrm{a}, \mathrm{b}}$ \\
\hline \multirow[t]{2}{*}{1.} & 9.679 & 1451 & Caryophyllene & 22.13 & $\mathrm{C}_{15} \mathrm{H}_{24}$ & $93^{\mathrm{a}}, 41,69,79,105,120,133,147,1$ \\
\hline & & & & & & $61,175,189,204^{b}$ \\
\hline \multirow[t]{2}{*}{2.} & 9.833 & 1428 & a-Bergamotene & 3.49 & $\mathrm{C}_{15} \mathrm{H}_{24}$ & $93^{\mathrm{a}}, 41,55,69,77,91,107,119,133$, \\
\hline & & & & & & $147,161,189,204^{b}$ \\
\hline \multirow[t]{2}{*}{3.} & 10.205 & NA & Humulene & 9.92 & $\mathrm{C}_{15} \mathrm{H}_{24}$ & $93^{a}, 41,69,77,80,107,121$ \\
\hline & & & & & & $147,204^{b}$ \\
\hline \multirow[t]{2}{*}{4.} & 10.348 & 1438 & Aromadendrene & 11.14 & $\mathrm{C}_{15} \mathrm{H}_{24}$ & $41^{\mathrm{a}}, 55,69,79,91,105,119$, \\
\hline & & & & & & $133,147,161,189,204^{b}$ \\
\hline 5. & 10.737 & 1485 & Curcumene & 20.89 & $\mathrm{C}_{15} \mathrm{H}_{22}$ & $119^{a}, 41,56,105,132,145,202^{b}$ \\
\hline \multirow[t]{2}{*}{6.} & 10.920 & 1493 & $\alpha$-Zingiberene & 17.00 & $\mathrm{C}_{15} \mathrm{H}_{24}$ & $93^{\mathrm{a}}, 41,69,77,105,119$ \\
\hline & & & & & & $161,204^{b}$ \\
\hline \multirow[t]{2}{*}{7.} & 11.046 & 1506 & $\beta$--Bisabolene & 1.12 & $\mathrm{C}_{15} \mathrm{H}_{24}$ & $69^{\mathrm{a}}, 41,93,109,119,135$ \\
\hline & & & & & & $161,204^{\mathrm{b}}$ \\
\hline \multirow[t]{2}{*}{8.} & 11.292 & 1526 & $\beta$-Sesquiphell- & 1.86 & $\mathrm{C}_{15} \mathrm{H}_{24}$ & 69 a $, 41,55,77,93,109,120$, \\
\hline & & & andrene & & & $133,161,204^{b}$ \\
\hline \multirow[t]{2}{*}{9.} & 12.288 & 1592 & Caryophyllene & 4.29 & $\mathrm{C}_{15} \mathrm{H}_{24} \mathrm{O}$ & $43^{\mathrm{a}}, 41,55,69,79,93,109$, \\
\hline & & & oxide & & & $121,220^{b}$ \\
\hline \multirow[t]{4}{*}{10} & 12.591 & NA & Bicyclo[3.1.1]hept & 1.80 & $\mathrm{C}_{10} \mathrm{H}_{18}$ & $55^{a}, 41,67,69,82,96,123,138^{b}$ \\
\hline & & & ane $2,6,6-$ & & & \\
\hline & & & trimethyl-,[IR- & & & \\
\hline & & & 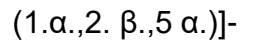 & & & \\
\hline \multirow[t]{2}{*}{11} & 12.768 & 1611 & zingiberenol & 2.81 & $\mathrm{C}_{15} \mathrm{H}_{26} \mathrm{O}$ & $69^{a}, 41,55,93,119,137,161$ \\
\hline & & & & & & $204,222^{b}$ \\
\hline \multirow[t]{2}{*}{12} & 13.449 & 1470 & 9-epi-(E)- & 1.35 & $\mathrm{C}_{15} \mathrm{H}_{24}$ & $91^{\mathrm{a}}, 41,55,69,79,105,119,133,14$ \\
\hline & & & Caryophyllene & & & $7,161,189,204^{b}$ \\
\hline \multirow[t]{3}{*}{13.} & 13.850 & NA & 7-epi-trans- & 1.22 & $\mathrm{C}_{15} \mathrm{H}_{26} \mathrm{O}$ & $119^{a}, 41,55,69,82,93,105$ \\
\hline & & & sesquisabinene & & & $161,204,223^{b}$ \\
\hline & & & hydrate & & & \\
\hline \multirow[t]{3}{*}{14.} & 13.970 & 1580 & $4,8,12-$ & 0.98 & $\mathrm{C}_{16} \mathrm{H}_{26}$ & $69^{a}, 41,81,95,107,218^{b}$ \\
\hline & & & trimethyltrideca- & & & \\
\hline & & & 1,7,11-tetraene & & & \\
\hline
\end{tabular}

Key:RT- Retention time in minutes, RI-Kovat values from literature, NA-Kovat values from literature not available,

$M S{ }^{a b} a=b a s e ~ p e a k, b=$ Molecular ion peak 


\section{DISCUSSION}

Major compounds found in the essential oil samples include: Caryophyllene, $20.85 \%$ and $22.13 \%$; $\alpha-$ Zingiberene, $16.55 \%$ and $17.00 \%$; Aromandendrene, $9.24 \%$ and $11.14 \%$; Humulene, $9.08 \%$ and $9.92 \%$; Caryophyllene oxide, $5.68 \%$ and $4.29 \%$ in the fresh and dried oils respectively, while Curcumene, $20.89 \%$ was found in the dried sample only. Trace amounts of hydrocarbons; $5.79 \%$ and $0.98 \%$ and $\beta$ - bisabolene; $0.40 \%$ and $1.12 \%$ were found in the fresh and dried samples while the fresh sample had a small amount of heterocyclic compounds (3.02\%) and esters (1.48\%) which were absent in the dried sample. Caryophyllene which is the major constituent of both essential oils has been found to be present in large amounts in the essential oils of many different spice and food plants, such as oregano, thyme, rosemary, cinnamon, curry and black pepper [12]. Analysis of Artemisia annua growing wild in Bulgaria shows that its essential oil contains $24.70 \%$ of caryophyllene [13], Curry leaves contain up to $35.00 \%$ [12], Cannabis sativa has up to $35.00 \%$ [14]. It is a dietary phytocannabinoid approved by US-FDA which improves renal functions, lowers the nephrotoxictiy of molecules like cisplatin and reduces creatinine [15]. Caryophyllene binds to the CB2 receptor in peripheral tissues and as a non psychoactive CB2 receptor, it modulates immune responses, inhibit inflammation and oedema formation and exhibit antinociceptive effects, also it is a potential target for the treatment of atherosclerosis and osteoporosis [14]. Aromandendrene which is another major constituent has been found as one of the major constituents of Eucalyptus microtheca leaf oil (aromadendrene, 18.31\%), from Semnan province [16], and in Eucalyptus sargentii (aromadendrene, $6.45 \%$ ), from Isfahan province [17]. Humulene, a constituent of both oils known to possess analgesic, anti-inflammatory, appetite depressant, and anticancer properties, have also been found to be present in the essential oils of aromatic plants such as Salvia officinalis [18], Lindera strychnifolia [19], up to $29.9 \%$ of the essential oils of Mentha spicata [20], $10.00 \%$ of the leaf oil of Litsea mushaensis [21], and (31.80 and $12.90 \%$ ) in the leaves and stem, respectively of Eclipta prostrata [22]. The dried essential oil of $G$. suaveolens contains $20.89 \%$ of curcumene which is one of the main constituents of turmeric root responsible for its anti-inflammatory properties.

\section{CONCLUSION}

This study provides information on the essential oil constituents of the fresh and dried leaves of Greenwayondendron suaveolens which has been scarce in literature. The presence of the sesquiterpenes as the major components of the fresh and dried oils justifies the traditional use of the plants in treating pains, headaches and inflammations.

\section{ACKNOWLEDGEMENTS}

The authors are grateful to Onwuamaoke, E. G. and Oderinde, E. F. who assisted in the data collection.

\section{COMPETING INTERESTS}

"Authors have declared that no competing interests exist."

\section{AUTHORS' CONTRIBUTIONS}

This work was carried out in collaboration among all Authors: 'Author OO' designed the study, performed the statistical analysis, wrote the protocol and wrote the first draft of the manuscript. 'Author OC' managed the analyses of the study. 'Author AO' managed the literature searches and type setting. 'All authors read and approved the final manuscript.

\section{CONSENT}

Not Applicable

\section{ETHICAL APPROVAL}

Not Applicable

\section{REFERENCES}

[1] Irvine JI. Comparative Study of the Chemical Composition and Mineral Element Content of Treculia africana Seeds and Seed Oils. J Food Eng. 2008; 40: 241-244.

[2] Datwyler SN, Shannon L, Weiblen GD. On the origin of the fig: Phylogenetic relationships of Moraceae from ndhF sequences. Am J of Bot. 2004; 91 (5): 767-777.

[3] Keay RWJ. The Trees of Nigeria, New York: Oxford University Press Oxford; 1989.

[4] Kolb B, Ettre LS. Static Headspace-Gas Chromatography: Theory and Practice, 2nd edition New York: Wiley-Interscience; 2006.

[5] David F, Pascal S. Review: Stir bar sorptive extraction for trace analysis. Mol Divers. 2007; 1152: 54-69.

[6] Judd WS, Campbell CS, Kellogg EA, Stevens PF, Donoghue MJ. Plant Systematics: A Phylogenetic Approach. Sinauer Associates, Sunderland, MA; 2008. [7] Bele MY, Focho DA, Egbe EA, Chuyong BG. Ethnobotanical survey of the uses of Annonaceae around mount Cameroon. Afr J Plant Sci. 2011; 5: 237-247.

[8] Tafokou RB. Greenwayodendron suaveolens (Engl. \& Diels) Verdc. In: Lemmens RHMJ, Louppe D, OtengAmoako AA. (Eds). Prota 7(2): Timbers/Bois d'oeuvre 2. [CD-Rom]. PROTA, Wageningen, Netherlands; 2011.

[9] Burkill HM. The useful plants of West Tropical Africa. 2nd Edition 1, Families A-D. Royal Botanic Gardens, Kew, Richmond, United Kingdom; 1985.

[10] Yoo H, Cremin PA, Zeng L, Garo E, Williams CT, Lee CM et al. Suaveolindole, a New MassLimited Antibacterial Indolosesquiterpene from Greenwayodendron suaveolens obtained via HighThroughput natural products chemistry methods. J Nat Prod. 2005; 68 (1): 122-124.

[11] Libbey LM. A paradox database for GC/MS and other volatiles. JEOR. 1991; 3:192-194. 
[12] Lima DK, Ballico LJ, Rocha-Lapa F, Gonçalves $\mathrm{HP}$, de Souza, LM, lacomini $\mathrm{M}$ et al. Evaluation of the antinociceptive, anti-inflammatory and gastric antiulcer activities of the essential oil from Piper aleyreanum C.DC in rodents. J Ethnopharmacol. 2012; 142 (1): 274-282.

[13] Tzenkova R, Kamenarska Z, Draganov A, Atanassov A. Composition of Artemisia Annua Essential Oil Obtained from Species growing Wild in Bulgaria. Biotechnol Biotec Equip. 2010; 24 (2): 18331835.

[14] Gertsch J, Leonti M, Raduner S, Racz I, Chen, J $Z$, Xie $X Q$ et al. Beta-caryophyllene is a dietary cannabinoid. Proc Natl Acad Sci USA. 2008; 105 (26): 9099-1004.

[15] Horváth B, Mukhopadhyay P, Kechrid M, Patel, V, Tanchian G, Wink DA et al. $\beta$-Caryophyllene ameliorates cisplatin-induced nephrotoxicity in a cannabinoid 2 receptor-dependent manner. Free Radic Biol Med. 2012; 52 (8):1325-33.

[16] Hashemi-Moghaddam $\mathrm{H}$, Kalatejari A, Afshari $\mathrm{H}$, Ebadi $\mathrm{AH}$. Microwave accelerated distillation of essential oils from the leaves of Eucalyptus microtheca: Optimization and comparison with conventional hydrodistillation. AJC. 2013; 25: 54235427.

[17] Safaei J, Batooli H. Chemical composition and antimicrobial activity of the volatile oil of Eucalyptus sargentii cultivated in central Iran. IJGP. 2010; 4:174177.

[18] Bouajaj S, Benyamna A, Bouamama $H$, Romane A, Falconieri D, Piras A et al. Antibacterial, allelopathic and antioxidant activities of essential oil of Salvia officinalis L. growing wild in the Atlas Mountains of Morocco. Nat Prod Res. 2013; 27 (18): 1673-1676.

[19] Cho IH, Lee HJ, Kim YS. (Differences in the volatile compositions of ginseng species (Panax sp.). J Agric Food Chem. 2012; 60 (31): 7616-7622.

[20] Chauhan SS, Prakash O, Padalia RC, Vivekanand PAK, Mathela CS. Chemical diversity in Mentha spicata: antioxidant and potato sprout inhibition activity of its essential oils. Nat Prod Commun. 2011; 6 (9): 1373-1378.

[21] Ho CL, Wang El, Tseng YH, Liao PC, Lin CN, Chou JC et al. Composition and antimicrobial activity of the leaf and twig oils of Litsea mushaensis and L. linii from Taiwan. Nat Prod Commun. 2010; 5 (11): 1823-1828.

[22] Ogunbinu AO, Flamini G, Cioni PL, Ogunwande I A, Okeniyi SO. Essential oil constituents of Eclipta prostrata (L.) and Vernonia amygdalina Delile. Nat Prod Commun. 2009; 4(3):421-424. 